DEPARTMENT OF THE INTERIOR

UNITED STATES GEOLOGICAL SURVEY
TO ACCOMPANY

WRI REPORT 83-4116-G

\title{
MAP SHOWING OUTCROPS OF BASALTIC ROCKS OF EARLY QUATERNARY AND TERTIARY AGE, BASIN AND RANGE PROVINCE, SOUTHERN CALIFORNIA
}

Compiled by Kurt Roggensack and David A. Lopez

\author{
INTRODUCTION
}

This map reoprt is one of a series of geologic and hydrologic maps covering ail or parts of states within the Basin and Range province of the western United states. The map reports contain detailed information on subjects that characterize the geohydrology of the province, including the ground-water hydrology, ground-water quality, surface distribution of selected rock types, tectonic conditions, areal geophysics, Pleistocene lakes and marshes, and mineral and energy resources. This is a part of the U.S. Geological Survey's program for geologic and hydrologic evaluation of the province to identify prospective regions for further study relative to isolation of high-level nuclear waste (Bedinger, Sargent, and Reed, 1984).

This map was prepared from published geologic maps and reports utilizing the project guidelines defined in sargent and Bedinger (1984). As used in this study, basaltic rocks include basaltic andesite and basalt. The map shows the known occurrences of basaltic rocks largely of Tertiary age. Locally, however, where basalts of Quaternary age were not differentiated from those of Tertiary age, the younger basalts have been included on the map. The Description of Map Units includes the geologic and, if available, radiometric age; lithology; thickness where available; and sources of data for the basaltic units in outlined and numbered areas within the counties of the study area. No information was available on the rock outcrops that are unnumbered. The listed radiometric ages do not necessarily represent the entire age range of a unit. 
DESCRIPTION OF MAP UNITS

(To convert feet ( $f t$ ) to meters, multiply feet by 0.3048 ;

to convert miles ( $\mathrm{mi}$ ) to kilometers, multiply miles by 1.6091]

\begin{tabular}{|c|c|c|c|}
\hline $\begin{array}{l}\text { County- } \\
\text { area } \\
\text { number }\end{array}$ & $\begin{array}{cc}\text { Geologic and } \\
\text { Map } & \text { radiometric age } \\
\text { symbol } & \text { in millions of } \\
\text { years (m.y.) }\end{array}$ & Lithology and comments & $\begin{array}{l}\text { References } \\
\text { for } \\
\text { county area }\end{array}$ \\
\hline
\end{tabular}

IMPERIAL COUNTY (IM)

\begin{tabular}{|c|c|c|c|c|}
\hline IM-1 & $\mathrm{Tb}$ & $\begin{array}{l}\text { Miocene } \\
13.2 \pm 2.5 \mathrm{~m} \cdot \mathrm{y} .\end{array}$ & $\begin{array}{l}\text { Basalt of Black Mountain: Fine-grained, } \\
\text { vesicular, augite-olivine-basalt flows. } \\
\text { Flows overlie volcaniclastic conglomerate } \\
\text { and are as much as } 200 \mathrm{ft} \text { thick. }\end{array}$ & $\begin{array}{l}\text { Crowe, 1978; } \\
\text { Henshaw, } 1942 \\
\text { Morton, } 1977\end{array}$ \\
\hline IM-2 & $\mathrm{Tb}$ & Tertiary & $\begin{array}{l}\text { Basalt flows, petrologically similar to the } \\
\text { basalt of Black Mountain (See IM-1); overlie } \\
\text { Tertiary sedimentary and volcanic rocks. }\end{array}$ & $\begin{array}{l}\text { Crowe, } 1978 ; \\
\text { Morton, } 1977\end{array}$ \\
\hline
\end{tabular}

$\therefore \quad$ INYO COUNTY (IN)

\begin{tabular}{|c|c|c|c|c|}
\hline$I N-1$ & $\mathrm{~Tb}$ & $\begin{array}{l}\text { Miocene } \\
10.8 \pm 1.0 \text { and } \\
10.9 \pm 0.2 \mathrm{~m} \cdot \mathrm{y}\end{array}$ & $\begin{array}{l}\text { Deep Springs valley basalt: Scoriaceous and } \\
\text { vesicular olivine-basalt and andesitic basalt } \\
\text { flows. Overlies monzonite, tuffaceous sand- } \\
\text { stone, sandstone, and conglomerate. Cross- } \\
\text { sectional thickness as much as } 300 \mathrm{ft} \text { (McKee, } \\
1968 \text { ). }\end{array}$ & $\begin{array}{l}\text { Dalrymple, } 1963 ; \\
\text { McKee, } 1968 ; \\
\text { Mckee and Nelson, } 1967 ; \\
\text { Robinson and others, 1968; } \\
\text { Strand, } 1967\end{array}$ \\
\hline$I N-2$ & $T b$ & $\begin{array}{l}\text { Miocene } \\
9.6 \pm 0.2 \mathrm{~m} . \mathrm{y} .\end{array}$ & $\begin{array}{l}\text { Coyote Flat basalt: Olivine-basalt flows, } \\
\text { dikes, and necks. Cross-sectional thickness } \\
0 \text { to more than } 500 \mathrm{ft} \text { (Bateman, 1965). }\end{array}$ & $\begin{array}{l}\text { Bateman, } 1965 ; \\
\text { Dalrymple, } 1963 ; \\
\text { Elliott and McKee, } 1982\end{array}$ \\
\hline IN -3 & $\mathrm{~Tb}$ & $\begin{array}{l}\text { Pliocene and } \\
\text { Miocene } \\
3.0 \pm 1.2 \text { to } \\
6.8 \pm 3.9 \mathrm{~m} \cdot \mathrm{y}\end{array}$ & $\begin{array}{l}\text { Locally scoriaceous olivine basalt, andesite } \\
\text { and trachyandesite flows, agglomerate, and } \\
\text { cinder cones. Locally overlies basaltic } \\
\text { fanglomerate; unit as much as } 1,000 \mathrm{ft} \text { thick. }\end{array}$ & $\begin{array}{l}\text { Burchfiel, } 1969 \text {; } \\
\text { Langenheim and others, 1982a; } \\
\text { McAllister, } 1956 \text {; } \\
\text { Nelson, } 1971 ; \text { Ross } 1967,1970\end{array}$ \\
\hline IN -4 & $\mathrm{QTb}$ & $\begin{array}{l}\text { Quaternary and } \\
\text { Tertiary }\end{array}$ & $\begin{array}{l}\text { Olivine basalt of oak Creek: Aphanitic } \\
\text { olivine-basalt flows as much as } 300 \mathrm{ft} \\
\text { thick in cross section (Moore, } 1963 \text { ). } \\
\text { Cross section also shows unit overlain by } \\
\text { alluvium and for } 2 \mathrm{mi} \text { in the subsurface. }\end{array}$ & $\begin{array}{l}\text { Du Bray, } 1981 \text {; } \\
\text { Moore, } 1963\end{array}$ \\
\hline IN -5 & $\mathrm{~Tb}$ & $\begin{array}{l}\text { Pliocene and } \\
\text { Miocene } \\
4.05 \pm 0.15 \text { to } \\
6.04 \pm 0.20 \mathrm{~m} \cdot \mathrm{y}\end{array}$ & $\begin{array}{l}\text { Porphyritic, olivine-basalt flows, dikes, } \\
\text { agglomerate, and cinder cones. Locally } \\
\text { interbedded tuff and lapilli tuff of basal- } \\
\text { tic to andesitic composition. Partly over- } \\
\text { lain by Quaternary basalt flows; unit more } \\
\text { than 500 ft thick. }\end{array}$ & $\begin{array}{l}\text { Hall, 1971; } \\
\text { Luedke and Smith, 1981; } \\
\text { McAllister, 1956; } \\
\text { Stinson, } 1977 \mathrm{~b}\end{array}$ \\
\hline \multirow[t]{2}{*}{ IN -6} & $\mathrm{~Tb}$ & $\begin{array}{l}\text { Pliocene and } \\
\text { Miocene } \\
4.03 \pm 0.12 \text { and } \\
7.16 \pm 0.22 \mathrm{~m} \cdot \mathrm{y}\end{array}$ & $\begin{array}{l}\text { Funeral Formation: Andesite and basalt } \\
\text { member, olivine-basalt flows and agglom- } \\
\text { erate as much as } 200 \mathrm{ft} \text { thick. }\end{array}$ & $\begin{array}{l}\text { Denny and Drewes, } 1965 ; \\
\text { Drewes, 1963; } \\
\text { Luedke and Smith, 1981; } \\
\text { McAllister, 1970, 1973 }\end{array}$ \\
\hline & & Tertiary & $\begin{array}{l}\text { Scoriaceous and porphyritic andesite and } \\
\text { basalt flows and intrusives included in } \\
\text { Greenwater volcanics; interbedded with } \\
\text { sediments of Copper Canyon Formation, and } \\
\text { clastics and evaporites of Furnace Creek } \\
\text { Formation, and in unnamed volcanic unit } \\
\text { below Furnace Creek Formation. Flows in } \\
\text { Furnace Creek Formation are highly altered } \\
\text { and fragmented. Overall thickness in any } \\
\text { one of the formations as much as } 500 \mathrm{ft} \text {. }\end{array}$ & \\
\hline
\end{tabular}




\begin{tabular}{|c|c|c|}
\hline \multirow[t]{2}{*}{ IN-7 } & $\mathrm{Tb}$ & Pliocene \\
\hline & $\mathrm{Tb}$ & $\begin{array}{l}\text { Pliocene } \\
3.56 \pm 0.10 \mathrm{~m} \cdot \mathrm{y} .\end{array}$ \\
\hline \multirow[t]{3}{*}{ IN -8} & $\mathrm{~Tb}$ & $\begin{array}{l}\text { Pliocene } \\
2.98 \pm 0.12 \text { to } \\
3.66 \pm 0.08 \mathrm{~m} . \mathrm{y} .\end{array}$ \\
\hline & & $\begin{array}{l}3.10 \pm 0.22 \text { and } \\
3.67 \pm 0.16 \mathrm{~m} . \mathrm{y} .\end{array}$ \\
\hline & & $\begin{array}{l}3.60 \pm 0.08 \text { and } \\
3.64 \pm 0.11 \mathrm{~m} . \mathrm{y} \text {. }\end{array}$ \\
\hline
\end{tabular}

$\begin{array}{lll}\text { IN-9 } & \text { Tb } & \begin{array}{l}\text { Pliocene } \\ 2.06 \pm 0.34 \mathrm{~m} \cdot \mathrm{y} .\end{array} \\ & & \\ \text { IN-10 } & \text { Tb } & \text { Tertiary }\end{array}$

Basalt of Silver Mountain: Slightly porphyritic basalt flows and pyroclastics in western one-half of the area.

Basalt of Upper Centennial Flat: Slightly porphyritic basalt flows and pyroclastics. Interbedded with pyroclastics and sediments of Coso Formation.

Basalt of Petroglyph Canyon: Moderately porphyritic, locally vesicular basalt flows and pyroclastics. Columnar and platy jointing. Flows 10 to $16 \mathrm{ft}$ thick and as much as $500 \mathrm{ft}$ in aggregate thickness. Crops out in central part of area.

Basalt and minor andesite flows and pyroclastics; flows 5 to $70 \mathrm{ft}$ thick. Located in southern part of area.

Basalt of Coso Peak: Porphyritic basalt flows and pyroclastics overlie quartz monzonite. Overlain by and interbedded with the basalt of Petroglyph Canyon. Crosssectional thickness as much as $500 \mathrm{ft}$ (Stinson, 1977).

Basalt of Rose valley: Cinder cone deposits and porphyritic basalt flows, locally containing granite xenoliths.

Basalt and andesite flows, local plugs and dikes. Cross-sectional thickness 0 to $250 \mathrm{ft}$ (Smith and others, 1968).
Duffield and Bacon, 1981

Duffield and Bacon, 1981; Stinson, $1977 \mathrm{a}$

Duffield and Bacon, 1981

Jennings and others, 1962; Smith and others, 1968

\section{KERN COUNTY (KE)}

\section{KE-1 \\ Tb \\ Pliocene}

KE-2 Tb Miocene

KE-3 Tb Early Miocene(?)

KE-4 Tb Miocene(?) and oligocene(?)
Fine-grained porphyritic basalt flows; dip $35^{\circ}$ west. Interbedded with sediments of Ricardo Formation and fanglomerate of Funeral Formation. Cross-sectional thickness 0 to 1,000 ft (Samsel, 1962).

Basalt flows, dikes, and sills, interbedded with pyroclastics of Kinnick Formation and siltstone of Bopesta Formation; dip $35^{\circ}$ northwest; weathers to sand-sized fragments. Cross-sectional thickness 0 to $800 \mathrm{ft}$ (Dibblee and Louke, 1970).

Saddleback Basalt: Fine-grained, massive basalt flows; maximum exposed thickness 200 ft. Cross sections show unit continuous in subsurface for more than $8 \mathrm{mi}$ and as thick as $600 \mathrm{ft}$ (Dibblee, 1958b).

Basalt flows within tuff breccia of Gem Hill Formation. Flows dip south, are locally vesicular, and locally have fracture partings. Thickness 0 to $200 \mathrm{ft}$.
Dibblee, $1967 \mathrm{~b}$;

Morton, 1977

Samsel, 1962;

Troxel and Morton, 1962

Dibblee 1959, 1967b; Dibblee and Louke, 1970; Troxel and Morton, 1962

Dibblee, 1958a, 1958b, 1967b; Jennings and others, 1962; Troxel and Morton, 1962

Dibblee, 1963, $1967 \mathrm{~b}$; Jennings and Strand, 1969 


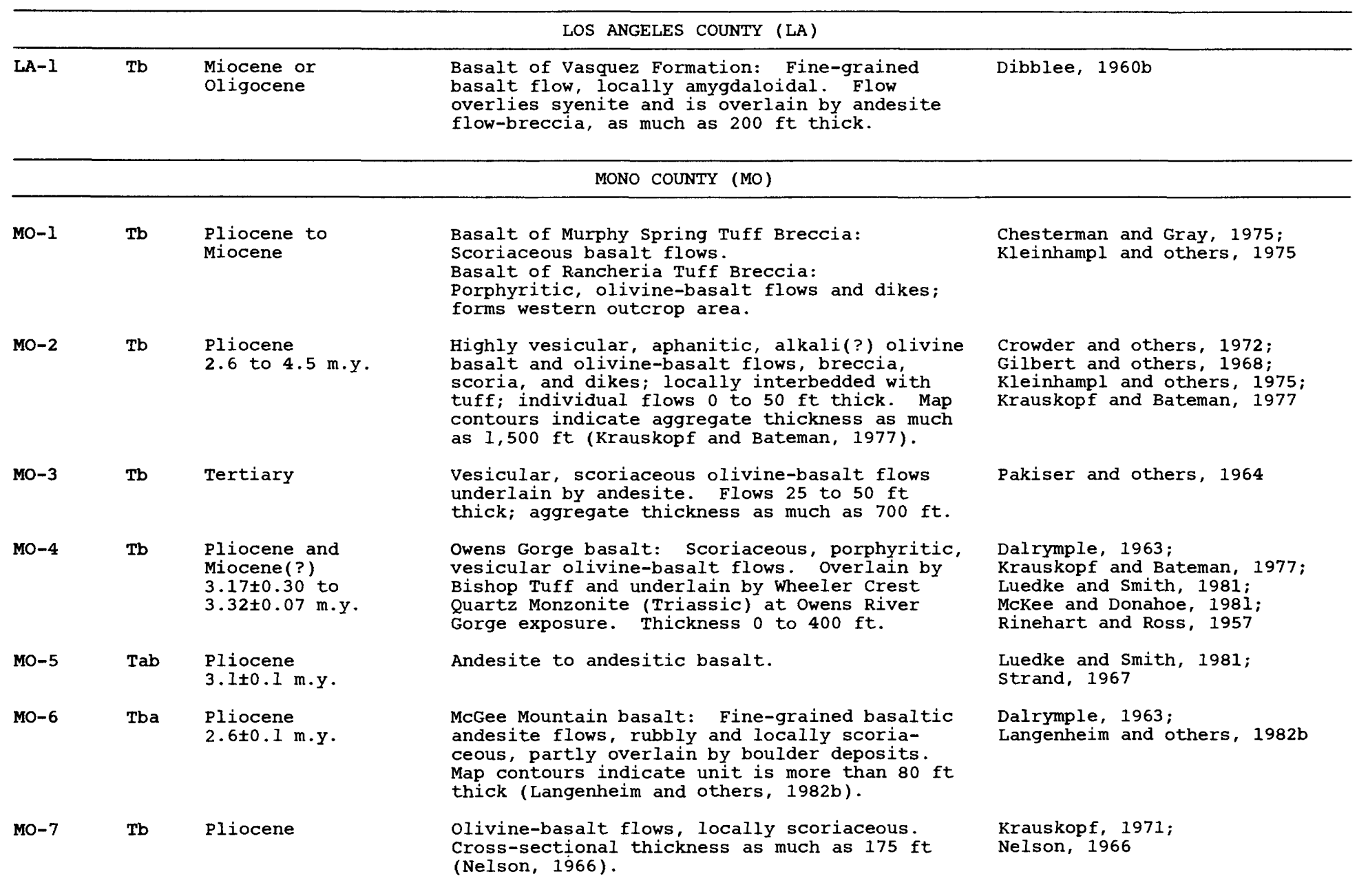

RI-I Tb Miocene(?)

RI-2 QTb $\begin{aligned} & \text { Quaternary and } \\ & \text { Tertiary }\end{aligned}$

Tertiary
0 to $5 \mathrm{~m} . \mathrm{y}$.
Basalt member of Coachella Fanglomerate and flows within Painted Hill Formation: Massive basalt and olivine basalt; overlies gneiss; 0 to $100 \mathrm{ft}$ thick.

Basaltic rocks.
Dibblee, $1967 \mathrm{~g}$;

Luedke and Smith, 1981;

Rogers, 1965, 1967

Luedke and Smith, 1981 
SB-1 Tb Tertiary

SB-2

Tb Tertiary

10 to $16+\mathrm{m} \cdot \mathrm{y}$.

SB-3

Tb Pliocene

$2.55 \pm 0.58 \mathrm{~m} \cdot \mathrm{y}$.

Miocene

13.6 to

$18.9 \pm 1.3 \mathrm{~m} \cdot \mathrm{y}$.

SB-4 Tb Miocene

Miocene

$S B-5$

TJb Tertiary to

Jurassic(?)

SB-6

Tb

Early Miocene

or older

SB-7

Tb Miocene

$S B-8$
Miocene or

oligocene
Basalt and andesite flows, and locally plugs and dikes. Cross-sectional thickness 0 to 250 ft (Smith and others, 1968).

Mount Davis Volcanics: Rhyolite dikes, plugs, domes, flows, and also, bedded pyroclastics in lower part in northern Castle Mountains. Described in Nevada as basaltic to rhyolitic lavas.

Black Mountain Basalt: Vesicular basalt flows; unconformably overlies sediments of Barstow Formation and volcanics of Pickhandle Formation. Overlain partly by alluvium. Flows 0 to $180 \mathrm{ft}$ thick. This unit comprises most outcrops in area.

Basalt and olivine-basalt flows interbedded with sediments of Barstow Formation and volcanics of Pickhandle and Jackhammer Formations. Crops out only in several small areas but more extensive in subsurface.

Barstow Formation: Three highly altered olivine-basalt flows interbedded with sandstone and conglomerate in lower member of the Barstow. Flows 0 to $20 \mathrm{ft}$ thick.

Alvord Peak Basalt: Nonporphyritic basalt and minor andesite flows, overlie tuffaceous beds of Clews Fanglomerate and overlain by sediments and volcanics of Spanish Canyon Formation and locally by Barstow Formation. Flows dip gently northwestward and are 0 to 400 ft in aggregate thickness. Unit comprises northern part of area.

Basalt flows, dip $40^{\circ}$ east, overlain by dacite and quartz latite, underlain by quartz latite. Thickness from stratigraphic column is $600 \mathrm{ft}$.

Red Buttes Quartz Basalt: Closely jointed quartz basalt flows, dip gently west to southwest. In northern and central Kramer Hills, unit overlain by fanglomerate and underlain by $360 \mathrm{ft}$ of extremely weathered olivine basalt. Unit in southwestern Kramer Hills overlain by alluvium and underlain by clay shale and quartz monzonite. Unit is as much as $300 \mathrm{ft}$ thick and probably correlative with Saddleback Basalt of area $\mathrm{KE}-3$.

Agglomerate, tuff, tuff breccia, welded tuff and volcanic conglomerate. Unit is possibly basaltic (E. J. Bortugno, California Division of Mines and Geology, written commun., 1982).

Basalt flows, breccia, and fanglomerate. Flows grade into andesite; interlayered with andesite, andesite breccia, and tuff breccia dips in varied directions. Cross-sectional thickness more than $500 \mathrm{ft}$.
Jennings and others, 1962 ;

Smith and others, 1968

Anderson and others, 1972;

Bingler and Bonham, 1973;

Luedke and Smith, 1981

Burke and others, 1982 ;

Dibblee, 1968

Byers, 1960

Dibblee, 1968

Barca, 1966

Dibblee, 1960a, 1967b;

Rogers, 1967

Dibblee, 1970

Rogers, 1967

Dibblee and Bassett, 1966a 
SB-9

Miocene or oligocene

\begin{tabular}{|c|c|c|}
\hline SB-10 & QTb & $\begin{array}{l}\text { Quaternary and } \\
\text { Tertiary } \\
2.03 \pm 1.2 \text { and } \\
2.1 \pm 0.2 \mathrm{~m} \cdot \mathrm{y} \text {. }\end{array}$ \\
\hline & $\mathrm{Tb}$ & Miocene \\
\hline
\end{tabular}

SB-11 Tb $\begin{aligned} & \text { Miocene and } \\ & \text { Oligocene }\end{aligned}$

SB-12 Tb Miocene to

SB-13 QTb Quaternary and Tertiary

Tb Pliocene

$2.1 \pm 0.2$ and

$2.03 \pm 1.2 \mathrm{~m} . \mathrm{Y}$.

Miocene or

oligocene

SB-14

Quaternary and Tertiary

SB-15 QTb $\begin{aligned} & \text { Quaternary and } \\ & \text { Tertiary }\end{aligned}$

$\mathrm{Tb}$

Miocene or oligocene
Scoriaceous basalt flow interbedded with finegrained sediments. 'As much as $100 \mathrm{ft}$ thick.

Basalt breccia, dips moderately in various directions and locally grades into fanglomerate. Cross-sectional thickness as much as $900 \mathrm{ft}$ (Dibblee and Bassett, 1966b). Crops out in southern one-half of area.

Basaltic rocks.

Agglomerate, tuff, tuff breccia, welded tuff, and volcanic conglomerate. Unit is possibly basaltic (E. J. Bortugno, California Division of Mines and Geology, written commun., 1982).

Basalt of Tropico Group: Massive, finegrained, locally vesicular basalt flows and sills which grade to andesite; dips $30^{\circ}$ southwest; overlies granite. Cross-sectional thickness more than 1,000 ft (Dibblee, 1970).

Locally vesicular, crumbly weathering basalt flows, dip $30^{\circ}$ southwest; interbedded with fanglomerate, andesite, and dacite. Crosssectional thickness greater than 1,000 ft.

Basalt of Lava Bed Mountains: Slightly to moderately vesicular basalt flows, overlies tuff breccia and partly overlain by fanglomerate and gravel; 0 to $200 \mathrm{ft}$ thick.

Basalt flows and cones, overlie alluvium and locally playas.

Fine-grained, massive basalt flows, interlayered with tuff breccia and fanglomerate; dip gently in various directions. Crosssectional thickness as much as $600 \mathrm{ft}$ (Dibblee, 1967c). Located in northeast part of area.

Basalt of Malpais crater: Fine-grained, vesicular basalt flows 0 to $100 \mathrm{ft}$ thick; underlain and partly overlain by alluvium. located in northern part of area. Elsewhere, fine-grained, massive basalt flows overlie the Tertiary old Woman(?) Sandstone and preTertiary quartz monzonite. Cross-sectional thickness as much as $500 \mathrm{ft}$ (Dibblee, 1967e).

Basalt of Ash Hill: Vesicular basalt flows and dikes. Flows overlie Tertiary sediments and volcanics and are partly overlain by alluvium. Cross-sectional thickness as much as $500 \mathrm{ft}$ (Dibblee, 1967a).

Massive, vesicular basalt flows, locally brecciated, and interbedded with tuff breccia and rhyolitic felsite. Flows dip gently in various directions. Cross-sectional thickness more than 1,000 ft (Dibblee, 1966).
Bassett and Kupfer, 1964; Dibblee, 1967c;

Dibblee and Bassett, 1966b

Bassett and Kupfer, 1964 ; Bishop, 1963; Dibblee, 1967c Dibblee and Bassett, 1966b; Rogers, 1967

Dibblee, 1964a, 1964b, 1970 ; Dibblee and Bassett, 1966

Dibblee, 1964b

Bassett and Kupfer, 1964;

Dibblee, $1966,1967 \mathrm{c}$;

Luedke and Smith, 1981

Dibblee, 1964a, 1964b $1964 \mathrm{c}, 1967 \mathrm{~d}, 1967 \mathrm{e}$,

$1967 \mathrm{f}, 1967 \mathrm{~g}$

Dibblee, 1966, 1967a 
Olivine basalt of Mopah Range: Vesicular olivine-basalt flows, scoriaceous at base; interbedded with tuffaceous sediments; 0 to

Calzia and Morton, 1980;

Miocene

Basalt of Vidal Valley: Vesicular basalt exposed only on west side of Mopah Range; 0 to $400 \mathrm{ft}$ thick.

Miocene

$14.5 \pm 0.3$ to

Basalt in northeast part of area.

$17.4 \pm 0.4 \mathrm{~m} \cdot \mathrm{y}$.

SAN DIEGO COUNTY (SD)

SD-1

Tba

Miocene

$16.9 \pm 0.5 \mathrm{~m} . \mathrm{y}$.

Alverson Andesite: Vesicular basalt and andesite flows, breccia, and intercalated volcaniclastics; overlies sediments of split Hoggatt, 1979 strand, 1962 Mountain Formation. Flows 0 to $50 \mathrm{ft}$ thick, aggregate thickness as much as $500 \mathrm{ft}$. 


\section{REFERENCES CITED}

Anderson, R. E., Longwell, C. R., Armstrong, R. L., and Marvin, R. F., 1972, Significance of K-Ar ages of Tertiary rocks from the Lake Mead region, Nevada-Arizona: Geological Society of America Bulletin, v. 83, p. 273-287.

Barca, R. A., 1966, Geology of the northern part of old Dad Mountain Quadrangle, San Bernardino County, California: California Division of Mines and Geology Map Sheet 7, scale $1: 62,500$.

Bassett, A. M., and Kupfer, G. H., 1964, A geologic reconnaissance in the southeastern Mojave Desert, California: California Division of Mines and Geology special Report 83, $43 \mathrm{p}$.

Bateman, P. C., 1965, Geology and tungsten mineralization of the Bishop dstrict, California: U.S. Geological Survey Professional Paper 470, $208 \mathrm{p}$.

Bedinger, M. S., Sargent, K. A., and Reed, J. E., 1984, Geologic and hydrologic characterization and evaluation of the Basin and Range province relative to the disposal of high-level radioactive waste, Part I--Introduction and guidelines:

U.S. Geological survey Circular 904-A, [in press].

Bingler, E. C., and Bonham, H. F., Jr., 1973, Reconnaissance geologic map of the McCullough Range and adjacent areas, Clark County, Nevada: Nevada Bureau of Mines and Geology Map 45, scale 1:125,000.

Bishop, C. C., compiler, 1963, Geologic map of California-Needles sheet: California Division of Mines and Geology, scale $1: 250,000$.

Burchfiel, B. C., 1969, Geology of the Dry Mountain Quadrangle, Inyo County, California: California Division of Mines and Geology Special Report 99, $19 \mathrm{p}$.

Burke, D. B., Hillhouse, J. W., McKee, E. H., Miller, S. T., and Morton, J. L., 1982, Cenozoic rocks in the Barstow basin area of southern California--stratigraphic relations, radiometric ages, and paleomagnetism: U.S. Geological Survey Bulletin 1529-E, $16 \mathrm{p}$.

Byers, F. M., Jr., 1960, Geology of the Alvord Mountain Quadrangle, San Bernardino County, California: U.S. Geological Survey Bulletin 1089-A, $71 \mathrm{p}$.

Calzia, J. P., and Morton, J. L., 1980, Compilation of isotopic ages within the Needles $1^{\circ} \times 2^{\circ}$ Quadrangle, California and Arizona: U.S. Geological Survey Open-File Report 80-1303, scale $1: 250,000$.

Carr, W. J., Dickey, D. D., and Quinlivan, W. D., 1980, Geologic map of the Vidal NW, Vidal Junction, and parts of the Savahia Peak SW, and Savahia Peak quadrangles, san Bernardino County, California: U.S. Geological Survey Miscellaneous Investigations Series Map I-1126, scale 1:24,000.

Chesterman, C. W., and Gray, C. H., Jr., 1975, Geology of the Bodie 15-minute Quadrangle, Mono County, California: California Division of Mines and Geology Map sheet 21, scale $1: 48,000$. 
Crowder, D. F., Robinson, P. F., and Harris, D. L., 1972, Geologic map of the Benton Quadrangle, Mono County, California, and Esmeralda and Mineral Counties, Nevada: U.S. Geological Survey Geologic Quadrangle Map GQ-1013, scale 1:62,500.

Crowe, B. M., 1978, Cenozoic volcanic geology and probable age of inception of basin-range faulting in the southeasternmost Chocolate Mountains, California: Geological society of America Bulletin, v. 89, no. 2, p. 251-264.

Dalrymple, G. B., 1963, Potassium-argon dates of some Cenozoic volcanic rocks of the Sierra Nevada, California: Geological Society of America Bulletin, v. 74, p. 379-390.

Denny, C. S., and Drewes, Harald, 1965, Geology of the Ash Meadows Quadrangle, Nevada-California: U.S. Geological Survey Bulletin 1181-L, $56 \mathrm{p}$.

Dibblee, T. W., Jr., 1958a, Geologic map of the Castle Butte Quadrangle, Kern County, California: U.S. Geological Survey Mineral Investigations Field studies Map MF-170, scale $1: 62,500$.

$1958 \mathrm{~b}$, Geologic map of the Boron Quadrangle, Kern and San Bernardino Counties, California: U.S. Geological survey Mineral Investigations Field studies Map MF-204, scale $1: 62,500$.

1959, Preliminary geologic map of the Mojave Quadrangle, California: U.S. Geological survey Mineral Investigations Field Studies Map MF-219, scale 1:62,500.

1960a, Geology of the Rogers Lake and Kramer quadrangles, California: U.S. Geological survey Bulletin 1089-B, p. $72-139$.

1960b, Geologic map of the Lancaster Quadrangle, Los Angeles County, California: U.S. Geological Survey Mineral Investigations Field studies Map MF-76, scale 1:62,500.

1963, Geology of the Willow Springs and Rosamond Quadrangles, California: U.S. Geological survey Bulletin 1089-C, p. 140-249.

1964a, Geologic map of the ord Mountains Quadrangle, San Bernardino County, California: U.S. Geological survey Miscellaneous Geologic Investigations Map I-427, scale $1: 62,500$.

1964b, Geologic map of the Rodman Mountains Quadrangle, San Bernardino County, California: U.S. Geological survey Miscellaneous Geologic Investigations Map I-430, scale $1: 62,500$.

1964c, Geologic map of the Lucerne Valley Quadrangle, San Bernardino County, California: U.S. Geological Survey Miscellaneous Geologic Investigations Map I-426, scale $1: 62,500$.

1966, Geologic map of the Lavic Quadrangle, San Bernardino County, California: U.S. Geological survey Miscellaneous Geologic Investigations Map I-472, scale 1:62,500.

1967a, Geologic map of the Ludlow Quadrangle, san Bernardino County, California: U.S. Geological Survey Miscellaneous Geologic Investigations Map I-477, scale 1:62,500. 
1967b, Areal geology of the western Mohave Desert, California: U.S. Geological Survey Professional Paper 522, $153 \mathrm{p}$.

1967c, Geologic map of the Broadwell Lake Quadrangle, San Bernardino County, California: U.S. Geological survey Miscellaneous Geologic Investigations Map I-478, scale $1: 62,500$.

1967d, Geologic map of the Emerson Lake Quadrangle, San Bernardino County, California: U.S. Geological survey Miscellaneous Geologic Investigations Map I-490, scale $1: 62,500$.

1967e, Geologic map of the old Woman springs Quadrangle, San Bernardino County, California: U.S. Geological survey Miscellaneous Geologic Investigations Map I-518, scale $1: 62,500$.

1967f, Geologic map of the Joshua Tree Quadrangle, San Bernardino and Riverside Counties, California: U.S. Geological Survey Miscellaneous Geologic Investigations Map I-516, scale 1:62,500.

1967g, Geologic map of the Morongo Valley Quadrangle, San Bernardino and Riverside Counties, California: U.S. Geological Survey Miscellaneous Geologic Investigations Map I-517, scale 1:62,500.

1968, Geology of the Fremont Peak and Opal Mountain Quadrangles, California: California Division of Mines and Geology Bulletin 188, $64 \mathrm{p}$.

1970, Geologic map of the Daggett Quadrangle, San Bernardino County, California: U.S. Geological Survey Miscellaneous Geologic Investigations Map I-592, scale $1: 62,500$.

Dibblee, T. W., Jr., and Bassett, A. M., 1966a, Geologic map of the Newberry Quadrangle, San Bernardino County, California:

U.S. Geological Survey Miscellaneous Geologic Investigations Map I-461, scale $1: 62,500$.

1966b, Geologic map of the Cady Mountains Quadrangle, San Bernardino County, California: U.S. Geological survey Miscellaneous Geologic Investigations Map I-467, scale $1: 62,500$.

Dibblee, T. W., Jr., and Louke, G. P., 1970, Geologic map of the Tehachapi Quadrangle, Kern County, California: U.S. Geological Survey Miscellaneous Geologic Investigations Map I-607, scale $1: 62,500$.

Drewes, Harald, 1963, Geology of the Funeral Peak quadrangle, California, on the east flank of Death Valley: U.S. Geological Survey Professional Paper 413, $78 \mathrm{p}$.

Du Bray, E. A., 1981, Generalized bedrock geologic map of the John Muir Wilderness, Fresno, Inyo, and Mono Counties, California: U.S. Geological survey Miscellaneous Field Studies Map MF-1185-A, scale 1:125,000.

Duffield, W. A., and Bacon, C. R., 1981, Geologic map of the Coso volcanic field and adjacent areas, Inyo county, California: U.S. Geological Survey Miscellaneous Investigations Series Map I-1200, scale 1:50,000. 
Elliot, G. S., and McKee, E. H., 1982, Geologic map of the Coyote $\mathrm{SE}$ and Table Mountain roadless areas, Inyo county, California: U.S. Geological Survey Miscellaneous Field Studies Map MF-1426-A, scale 1:62,500.

Gilbert, C. M., Christensen, M. N., Al-Rawi, Yehya, and Lajoie, K. R., 1968, Structural and volcanic history of Mono basin, California-Nevada, in Coats, R. R., Hay, R. L., and Anderson, C. A., eds., studies in volcanology--A memoir in honor of Howell Williams: Geological Society of America Memoir 116, p. 275-329.

Hall, W. E., 1971, Geology of the Panamint Butte Quadrangle, Inyo County, California: U.S. Geological Survey Bulletin 1299, $67 \mathrm{p}$.

Henshaw, P. C., 1942, Geology and mineral resources of the Cargo Muchacho Mountains, Imperial County, California: California Journal of Mines and Geology, v. 38, p. 147-196.

Hoggatt, W. C., 1979, Geologic map of Sweeney Pass Quadrangle, San Diego County, California: U.S. Geological survey OpenFile Report 79-754, $28 \mathrm{p}$.

Jennings, C. W., compiler, 1961, Geologic map of California-Kingman sheet: California Division of Mines and Geology, scale $1: 250,000$.

1967, compiler, Geologic map of California--Salton Sea sheet: California Division of Mines and Geology, scale $1: 250,000$.

Jennings, C. W., Burnett, J. L., and Troxel, B. W., compilers, 1962, Geologic map of California--Trona sheet: California Division of Mines and Geology, scale 1:250,000.

Jennings, C. W., and Strand, R. G., compilers, 1969, Geologic map of California--Los Angeles sheet: California Division of Mines and Geology, scale 1:250,000.

Kleinhampl, F. J., Davis, W. E., Silberman, M. L., Chesterman, C. W., Chapman, R. H., and Gray, C. H., Jr., 1975, Aeromagnetic and limited gravity studies and generalized geology of the Bodie Hills region, Nevada and California: U.S. Geological Survey Bulletin 1384, $38 \mathrm{p}$.

Koenig, J. B., compiler, 1963, Geologic map of California--Walker Lake sheet: California Division of Mines and Geology, scale $1: 250,000$.

Krauskopf, K. B., 1971, Geologic map of the Mt. Barcroft quadrangle, California-Nevada: U.S. Geological Survey Geologic Quadrangle Map GQ-960, scale 1:62,500.

Krauskopf, K. B., and Bateman, P. C., 1977, Geologic map of the Glass Mountain Quadrangle, Mono County, California, and Mineral County, Nevada: U.S. Geological survey Geologic Quadrangle Map GQ-1099, scale $1: 62,500$.

Langenheim, V. A. M., Donahoe, J. L., and McKee, E. H., 1982a, Geologic map of the Andreas Mountain, Mazourka, and Paiute roadless areas, Inyo County, California: U.S. Geological Survey Miscellaneous Field studies Map MF-1492-A, scale $1: 62,500$. 
1982b, Geologic map of the Laurel-McGee and wheeler Ridge roadless areas, Inyo and Mono Counties, California: U.S. Geological Survey Miscellaneous Field studies Map MF-1411-A, scale $1: 62,500$.

Luedke, R. G., and Smith, R. L., 1981, Map showing distribution, composition, and age of late Cenozoic volcanic centers in California and Nevada: U.S. Geological Survey Map I-1091-C, scale $1: 1,000,000,2$ sheets.

Matthews, R. A., and Burnett, J. L., compilers, 1965, Geologic map of California--Fresno sheet: California Division of Mines and Geology, scale 1:250,000.

McAllister, J. F., 1956, Geology of the Ubehebe Peak Quadrangle, California: U.S. Geological Survey Geologic Quadrangle Map GQ-95, scale $1: 62,500$.

1970, Geology of the Furnace Creek borate area, Death Valley, Inyo County, California: California Division of Mines and Geology Map sheet 14, scale 1:24,000.

1973, Geologic map and sections of the Amargosa Valley borate area-southeast continuation of the Furnace creek area, Inyo County, California: U.S. Geological survey Miscellaneous Geologic Investigations Map I-782, scale $1: 24,000$.

McKee, E. H., 1968, Geology of the Magruder Mountains area, Nevada-California: U.S. Geological Survey Bulletin 1251-H, $40 \mathrm{p}$.

MCKee, E. H., and Donahoe, J. L., 1981, Geologic map of the Benton Range further planning (RARE II) area, Mono County, California: U.S. Geological Survey Miscellaneous Field Studies Map MF-1317-A, scale 1:62,500.

McKee, E. H., and Nelson, C. A., 1967, Geologic map of the Soldier Pass Quadrangle, California and Nevada: U.S. Geological Survey Geologic quadrangle Map GQ-654, scale $1: 62,500$.

Moore, J. G., 1963, Geology of the Mount Pinchot quadrangle, southern Sierra Nevada, California: U.S. Geological Survey Bulletin 1130, $152 \mathrm{p}$.

Morton, P. K., 1977, Geology and mineral resources of Imperial County, California: California Division of Mines and Geology County Report 7, 104 p.

Nelson, C. A., 1966, Geologic map of the Blanco Mountain Quadrangle, Inyo and Mono Counties, California: U.S. Geological Survey Geologic Quadrangle Map GQ-529, scale 1:62,500. 1971, Geologic map of the Waucoba spring Quadrangle, Inyo County, California: U.S. Geological survey Geologic quadrangle Map GQ-921, scale 1:62,500.

Pakiser, L. C., Kane, M. F., and Jackson, W. H., 1964, Structural geology and volcanism of Owens Valley region, California-A geophysical study: U.S. Geological survey Professional Paper $438,68 \mathrm{p}$.

Rinehart, C. D., and Ross, D. C., 1957, Geologic map of the Casa Diablo Mountain Quadrangle, California: U.S. Geological Survey Geologic Quadrangle Map GQ-99, scale 1:62,500. 
Robinson, P. T., McKee, E. H., and Moiola, R. J., 1968, Cenozoic volcanism and sedimentation, silver Peak region, western Nevada and adjacent California, in Coats, R. R., Hay, R. L., and Anderson, C. A., eds., studies in volcanology--A memoir in honor of Howell Williams: Geological Society of America Memoir 116, p. 577-611.

Rogers, T. H., compiler, 1965, Geologic map of California--Santa Ana sheet: California Division of Mines and Geology, scale $1: 250,000$.

1967, Geologic map of California--San Bernardino sheet:

California Division of Mines and Geology, scale 1:250,000.

Ross, D. C., 1967, Geologic map of the Waucoba Wash Quadrangle, Inyo County, California: U.S. Geological survey Geologic Quadrangle Map, GQ-612, scale $1: 62,500$.

1970, Pegmatitic trachyandesite plugs and associated volcanic rocks in the saline Range-Inyo Mountains region, California: U.S. Geological survey Professional Paper 614-D, $29 \mathrm{p}$.

Samsel, H. S., 1962, Geology of the southeast quarter of the Cross Mountain Quadrangle, Kern County, California: California Division of Mines and Geology Map sheet 2, scale $1: 40,000$.

Sargent, K. A., and Bedinger, M. S., 1984, Geologic and hydrologic characterization and evaluation of the Basin and Range province relative to the disposal of high-level radioactive waste, Part II--Geologic and hydrologic characterization: U.S. Geological survey Circular 904-B, [in press].

Smith, A. R., compiler 1964, Geologic map of California-Bakersfield sheet: California Division of Mines and Geology, scale $1: 250,000$.

Smith, G. I., Troxel, B. W., Gray, C. H., Jr., and von Huene, Roland, 1968, Geologic reconnaissance of the slate Range, San Bernardino and Inyo Counties, California: California Division of Mines and Geology special Report 96, $33 \mathrm{p}$.

Stinson, M. C., 1977a, Geology of the Haiwee Reservoir 15-minute Quadrangle, Inyo County, California: California Division of Mines and Geology Map sheet 37, scale 1:62,500.

1977b, Geology of the Keeler 15-minute Quadrangle, Inyo County, California: California Division of Mines and Geology Map sheet 38 , scale $1: 62,500$.

Strand, R. G., compiler, 1962, Geologic map of California--San Diego-El Centro sheet: California Division of Mines and Geology, scale $1: 250,000$.

1967, Geologic map of California--Mariposa sheet: California Division of Mines and Geology, scale 1:250,000.

Streitz, Robert, and Stinson, M.C., compilers, 1974, Geologic map of California--Death Valley sheet: California Division of Mines and Geology, scale 1:250,000.

Troxel, B.W., and Morton, P.K., 1962, Mines and mineral resources of Kern County, California: California Division of Mines and Geology County Report 1, 370 p. 